\title{
Fermentative degradation of glutarate via decarboxylation by newly isolated strictly anaerobic bacteria
}

\author{
Carola Matthies ${ }^{1}$ and Bernhard Schink ${ }^{2}$ \\ 1 Lehrstuhl Mikrobiologie I, Eberhard-Karls-Universität, Auf der Morgenstelle 28, W-7400 Tübingen, Federal Republic of Germany \\ 2 Fakultät für Biologie, Universität Konstanz, Postfach 5560, W-7750 Konstanz, Federal Republic of Germany
}

Received August 6, 1991/ Accepted November 8, 1991

\begin{abstract}
Two strains of new strictly anaerobic, gramnegative bacteria were enriched and isolated from a freshwater (strain WoG13) and a saltwater (strain CuG11) anoxic sediment with glutarate as sole energy source. Strain WoGl3 formed spores whereas strain CuGl1 did not. Both strains were rod-shaped, motile bacteria growing in carbonate-buffered, sulfide-reduced mineral medium supplemented with $2 \%$ of rumen fluid. Both strains fermented glutarate to butyrate, isobutyrate, $\mathrm{CO}_{2}$, and small amounts of acetate. With methylsuccinate, the same products were formed, and succinate was fermented to propionate and $\mathrm{CO}_{2}$. No sugars, amino acids or other organic acids were used as substrates. Molar growth yields (Ys) were very small $(0.5-0.9 \mathrm{~g}$ cell dry mass $/ \mathrm{mol}$ dicarboxylate). Cells of strain WoGl3 contained no cytochromes, and the DNA base ratio was $49.0 \pm 1.4 \mathrm{~mol} \%$ guanine-plus-cytosine. Enzyme activities involved in glutarate degradation could be demonstrated in cell-free extracts of strain WoG13. A pathway of glutarate fermentation via decarboxylation of glutaconyl-CoA to crotonyl-CoA is suggested which forms butyrate and partly isobutyrate by subsequent isomerization.
\end{abstract}

Key words: Anaerobic degradation - Dicarboxylic acids - Glutarate - Glutaconyl - CoA decarboxylase

Fermentative degradation of short-chain dicarboxylic acids such as oxalate, malonate, or succinate has been documented. The isolated bacteria grow with these dicarboxylates as sole energy sources and decarboxylate them to the respective fatty acids (Schink and Pfennig 1982; Allison et al. 1985; Smith et al. 1985; Dehning and Schink $1989 \mathrm{a}, \mathrm{b}$; Dehning et al. 1989; Denger and Schink 1990). With oxalate and succinate, the free energy change of this decarboxylation reaction $\left(\Delta \mathrm{G}^{\circ \prime} \approx-30 \mathrm{~kJ} \cdot \mathrm{mol}^{-1}\right.$, Thauer et al. 1977) is conserved in an ion gradient across the membrane which serves as sole energy source for ATP synthesis

Offprint requests to: B. Schink
(Anantharam et al. 1989; Hilpert et al. 1984). Only little is known about fermentative degradation of long-chain dicarboxylic acids with more than 4 carbon atoms. Glutarate can be used as growth substrate by sulfatereducing bacteria (Imhoff-Stuckle and Pfennig 1983; Bak and Widdel 1986; Szewzyk and Pfennig 1987; Schnell et al. 1989) and nitrate-reducing pseudomonads (strains K172 and S2; B. Seyfried, personal communication). In both cases, glutarate is oxidized probably in a similar way as in aerobic microorganisms: In Pseudomonas fluorescens, glutarate is activated to glutaryl-CoA which is oxidized to glutaconyl-CoA by glutaryl-CoA dehydrogenase and decarboxylated to crotonyl-CoA. The latter is further metabolized by the well-known steps of $\beta$-oxidation of fatty acids (Numa et al. 1964).

In methanogenic enrichment culture, glutarate was shown to be degraded completely to methane and $\mathrm{CO}_{2}$ with butyrate and isobutyrate as intermediates (Stieb 1985).

In this paper, the isolation and characterization of a strictly anaerobic glutarate-fermenting bacterium in pure culture is presented. Enzymes involved in glutarate degradation were measured, and a catabolic pathway is proposed.

\section{Material and methods}

\section{Sources of organisms}

Enrichment cultures with glutarate as sole organic substrate were inoculated with anoxic sediment of a polluted creek near Konstanz (WoGl), FRG, domestic sewage sludge (KoGl) and the marine enrichment culture with black mud of the North Sea coast near Cuxhaven, FRG, (CuGl).

Desulfovibrio vulgaris strain Marburg and Methanospirillum hungatei strain SK were kindly provided by Prof. Dr. R. K. Thauer, Marburg, FRG, and Prof. Dr. F. Widdel, Munich, FRG.

Acetobacterium woodii (DSM 1030) and Escherichia coli strain K12 (DSM 498) were obtained from the Deutsche Sammlung von Mikroorganismen GmbH, Braunschweig, FRG.

\section{Media and growth conditions}

All procedures for anaerobic cultivation and isolation were the same as described earlier (Widdel and Pfennig 1981; Pfennig and 
Trüper 1981). The mineral salts medium contained $30 \mathrm{mM}$ sodium bicarbonate as buffer and $1 \mathrm{mM}$ sodium sulfide as reducing agent and sulfur source. Trace element solution SL $10(1 \mathrm{ml} / 1)$ and selenite-tungstate solution $(1 \mathrm{ml} / \mathrm{l})$ as well as 7 -vitamines solution were added to the medium from sterile stock solutions (Widdel and Pfennig 1981; Widdel et al. 1983).

Growth experiments were carried out in 22-ml-screw-cap tubes in which cell turbidity was measured at $600 \mathrm{~nm}$ wavelength with a Spectronic 20 spectrophotometer (Milton Roy, Rochester, NY, USA). All cultures were incubated at $30^{\circ} \mathrm{C}$.

\section{Cytological characterization}

Gram staining was carried out according to Bartholomew (1962), with Acetobacterium woodii and Desulfovibrio vulgaris strain Marburg as reference organisms.

Flagella were stained as described by Blenden and Goldberg (1965).

Spore formation was checked for in mineral salts medium with $20 \%$ soil extract and $5 \mathrm{mg} \mathrm{MnSO}_{4} / \mathrm{l}$. Alternatively, the latter medium was supplemented with $0.1 \%$ tryptone, $5 \mathrm{mM}$ glutarate or $10 \mathrm{mM}$ xylose (modified after Hollaus and Sleytr 1972). Heat resistance of spores was checked for by pasteurization $\left(80^{\circ} \mathrm{C}\right.$ for 10 min).

Cytochromes were checked for in cell-free extracts of glutarategrown cells through redox difference spectra taken with an Uvikon 860 spectrophotometer (Kontron, Zürich, Switzerland).

\section{Chemical analyses}

Fatty acids, dicarboxylic acids, methane, and carbon dioxide were assayed by gas chromatography. Fatty acids were determined by a method modified after Platen and Schink (1989). Acetate, butyrate and isobutyrate were separated by increasing the column temperature from $120^{\circ} \mathrm{C}$ to $150^{\circ} \mathrm{C}$ at a rate of $25^{\circ} \mathrm{C} / \mathrm{min}$. Propionate was measured at $120^{\circ} \mathrm{C}$ column temperature. All samples were acidified before injection with formic acid $(0.5 \mathrm{M}$ final concentration). Dicarboxylic acids were quantified as methyl esters (Metcalfe et al. 1966) with a capillary column according to Dehning and Schink (1989b). Conditions were slightly modified: detector and injector temperature $225^{\circ} \mathrm{C}$, column temperature $140^{\circ} \mathrm{C}$ (succinate) or $150^{\circ} \mathrm{C}$ (glutarate, methylsuccinate), with malonate as internal standard.

The guanine-plus-cytosine content of the DNA was determined after preparation of DNA (Marmur 1961) and thermal denaturation (De Ley et al. 1970). Escherichia coli strain K12 was taken as reference.

Protein was determined with the micro-buiret method ( $\mathrm{Za}$ menhoff 1957).

\section{Enzyme assays}

If not indicated otherwise, all enzyme assays were carried out with cell-free extracts prepared from glutarate-grown cells of strain WoG13 under anaerobic conditions (Matthies and Schink 1991). Photometric assays were performed in a spectrophotometer model 100-40 (Hitachi, Tokyo, Japan). A linear relationship of activity and protein concentration was checked for with all enzyme activities.

Glutaryl-CoA synthetase (EC 6.2.1.6) was measured after Brandis-Heep et al. (1983) using glutaryl-CoA instead of succinyl-CoA.

Acyl-CoA: acetate CoA transferase (EC 2.8.3.8) was assayed by the propionyl-CoA : acetate CoA transferase assay described by Hilpert et al. (1984).

Glutaryl-CoA dehydrogenase (EC 1.3.99.7) and butyryl-CoA dehydrogenase (EC 1.3.99.2) were determined by a modified succinate dehydrogenase assay (Stams et al. 1984). The reaction mixture contained: potassium phosphate buffer, $\mathrm{pH} 7.5,50 \mathrm{mM}$; potassium hexacyanoferrate (III), $1 \mathrm{mM}$; phenazine methosulfate, $0.1 \mathrm{mM}$; glutaryl-CoA or butyryl-CoA, $0.5 \mathrm{mM}$; cell extract, $0.1-0.25 \mathrm{mg}$ protein $\cdot \mathrm{ml}^{-1}$

Glutaconyl-CoA decarboxylase (EC 4.1.1.-) was determined by a photometric test modified after Buckel (1986). The assay mixture contained: potassium phosphate buffer, $50 \mathrm{mM}$, pH 7.0, $2.5 \mathrm{mM}$ dithioerythritol; auxiliary enzyme mixture (acetyl-CoA:glutaconate CoA transferase, crotonase, 3-hydroxybutyryl-CoA dehydrogenase, $\beta$-ketothiolase, phosphate acetyl transferase), $0.2 \mathrm{mg}$ protein $\cdot \mathrm{ml}^{-1}$; coenzyme A, $1 \mathrm{mM}$; acetyl phosphate, $1 \mathrm{mM}$; NAD, $10 \mathrm{mM} ; \mathrm{NaCl}, 20 \mathrm{mM} ; \mathrm{Na}_{2}$-glutaconate, $1 \mathrm{mM}$; cell-free extract, $0.1-0.25 \mathrm{mg}$ protein $\cdot \mathrm{ml}^{-1}$.

Methylmalonyl-CoA decarboxylase (EC 4.1.1.41) was measured following methylmalonyl-CoA absorption decrease at $232 \mathrm{~nm}$ in the presence of phosphate acetyl transferase and arsenate (Hilpert and Dimroth 1983).

Acetate kinase (EC 2.7.2.1.) and phosphate acetyl transferase (EC 2.3.1.8) were determined by standard methods (Bergmeyer 1974). $\beta$-Ketothiolase (EC 2.3.1.19) and 3-hydroxybutyryl-CoA dehydrogenase (EC 1.1.1.157) were measured according to Lynen and Ochoa (1953). Crotonase (EC 4.2.1.17) was assayed following crotonyl-CoA absorption decrease at $263 \mathrm{~nm}$ (Moskowitz and Merrick 1969).

Glutaconate CoA-transferase was determined as described by Buckel (1986).

\section{Chemicals}

All chemicals used were of reagent grade quality and obtained from Merck, Darmstadt; Fluka, Neu-Ulm; Sigma, Deisenhofen; Boehringer, Mannheim, and Biomol, Hamburg, FRG. Gases were obtained from Messer-Griesheim, Darmstadt, FRG.

\section{Results}

\section{Enrichment and isolation}

Mineral salts medium with $10 \mathrm{mM}$ glutarate as sole source of carbon and energy was inoculated with anoxic sediment samples. After 4-7 weeks, turbidity increased and gas production started. The enrichment cultures were transferred several times, and motile spore-forming rods, large refractive rods, and methanogens shaped like Methanospirillum hungatei were enriched, but no glutarate-degrading bacterium could be isolated in pure culture. However, after the cultures were incubated with enhanced glutarate concentration $(20 \mathrm{mM})$, long, motile, rodshaped cells dominated. After more than 10 transfers, the subcultures CuGl, WoGl and KoGl grew up within 2-5 days. Addition of $30 \mathrm{mM}$ bromoethane-sulfonate, a specific inhibitor of methanogenesis (Sparling and Daniels 1987), to the medium did not inhibit glutarate degradation, but enriched long, motile rods in the cultures.

Isolation of glutarate-degrading bacteria in pure culture was attempted by diluting the culture in agar shake series. White, lentil-shaped colonies developed within $1-2$ weeks. Picked colonies from the last positive tube of a second agar dilution series started growth only if they were transferred into filter-sterilized spent growth medium of the enrichment culture amended with additional $0.5 \mathrm{mM}$ sodium sulfide. Two isolates, WoGl3 from freshwater and CuGl1 from a marine sediment, were obtained by this procedure. Purity was checked microscopically and by growth tests in complex AC-medium (Difco, Ann Arbor, Mich., USA) in the presence or absence of added glutarate.

Both isolated strains were very similar with respect to morphology, gram reaction, and physiological proper- 
ties. Therefore, only strain WoGl3 was chosen for detailed characterization.

\section{Morphology and cytology}

Both strains were long, rod-shaped cells, $4.5-6.5 \mu \mathrm{m}$ $\times 0.8 \mu \mathrm{m}$ in size (Fig. $1 \mathrm{a}, \mathrm{b}$ ). Motility was observed only in growing cultures. Cells moved in a twisting and tumbling manner. Flagella staining revealed one subpolarly inserted flagellum (Fig. 1c). Motility was lost after about 6 months of cultivation. Both strains stained gram-negative, and the $\mathrm{KOH}$ test (Gregersen 1978) showed the typical reaction of gram-negative bacteria. Part of the cells of strain WoG13 formed spores in well-growing cultures or in colonies in agar. Spores were formed at the terminal part of the cells (Fig. 1a), and survived pasteurization at $80^{\circ} \mathrm{C}$ for $10 \mathrm{~min}$. With strain CuG11, spore formation was not observed. The DNA base ratio of strain WoG13 determined by thermal denaturation was $49.0 \pm 1.4 \mathrm{~mol} \%$ guanine-plus-cytosine. No cytochromes could be detected in redox difference spectra of crude cell extracts.

\section{Physiology}

Growth of strains WoGl3 and CuGll occurred only under strictly anaerobic conditions. Strain WoGl3 grew well in freshwater medium containing $1 \mathrm{~g} / 1 \mathrm{NaCl}$ and $0.4 \mathrm{~g} / 1 \mathrm{MgCl}_{2} \cdot 6 \mathrm{H}_{2} \mathrm{O}$, and no growth was detected in saltwater medium $\left(20 \mathrm{~g} / 1 \mathrm{NaCl}, 3 \mathrm{~g} / 1 \mathrm{MgCl}_{2} \cdot \mathrm{H}_{2} \mathrm{O}\right)$. Strain CuGl1 grew well in both media. Strain WoG13 could also be grown in freshwater medium containing $20 \mathrm{mM}$ potassium phosphate as buffer. Both strains required growth supplines provided in the enrichment medium by partner bacteria. With strain WoGl3, reproducible growth was obtained with $2 \%$ rumen fluid to the glutarate-containing freshwater mineral medium. With $0.05 \%$ yeast extract, $0.1 \%$ pig manure extract, or $0.1 \%$ casamino acids, similar cell densities were obtained, but growth lag phases increased. No growth was observed with any of these supplines alone. Optimal growth of strain WoGl3 was found at $37^{\circ} \mathrm{C}\left(\mu=0.062, t_{\mathrm{d}}=11 \mathrm{~h}\right)$.
Cells grew well within a $\mathrm{pH}$ range of 7.1-8.2. No growth was detected below $20^{\circ} \mathrm{C}$ or above $37^{\circ} \mathrm{C}$, or at $\mathrm{pH}<6.0$.

Only glutarate, methylsuccinate, and succinate could be used as growth substrates by strain WoG13. Neither sugars, amino acids, organic acids nor other dicarboxylic acids were degraded (Table 1). Butyrate, isobutyrate, $\mathrm{CO}_{2}$ and small amounts of acetate were formed as products of glutarate and methylsuccinate fermentation. Succinate was fermented to propionate and $\mathrm{CO}_{2}$. Strain $\mathrm{CuGl1}$ used the same substrates and formed the same products.

A growth curve of strain WoGl3 (Fig. 2) illustrates correlation of growth with glutarate consumption and formation of butyrate, isobutyrate, and acetate.

\section{Stoichiometry and growth yields}

Stoichiometry of substrate utilization and product formation was determined with both strains, WoGl3 and

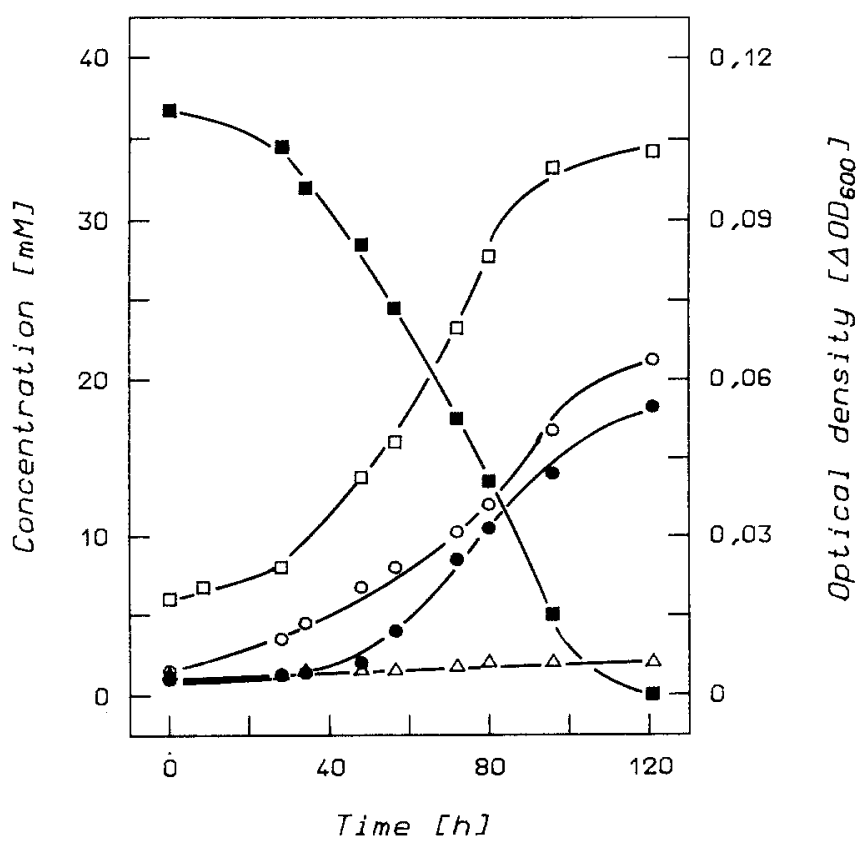

Fig. 2. Growth of strain WoGl3 with glutarate (ם): cell density $(\square)$ and formation of butyrate $(0)$, isobutyrate $(\mathbf{O})$, and acetate $(\triangle)$
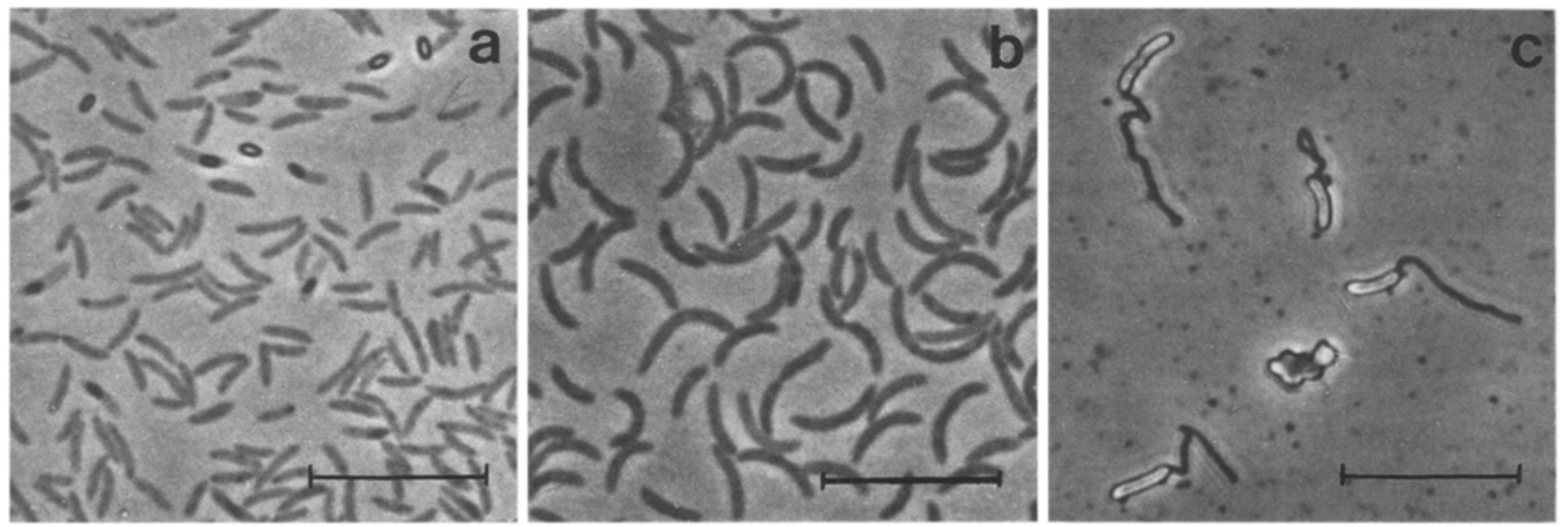

Fig. 1a-c. Phase contrast photomicrographs of the isolates WoGl3 and CuGl1. $a$ Vegetative cells, free spores and spore formation of strain WoGl3; $b$ vegetative cells of strain CuGl1; $c$ vegetative cells of strain WoGl3 with stained flagella. Bars equal $10 \mu \mathrm{m}$ 
Table 1. Fermentation stoichiometries and growth yields of strains WoG13 and CuG11

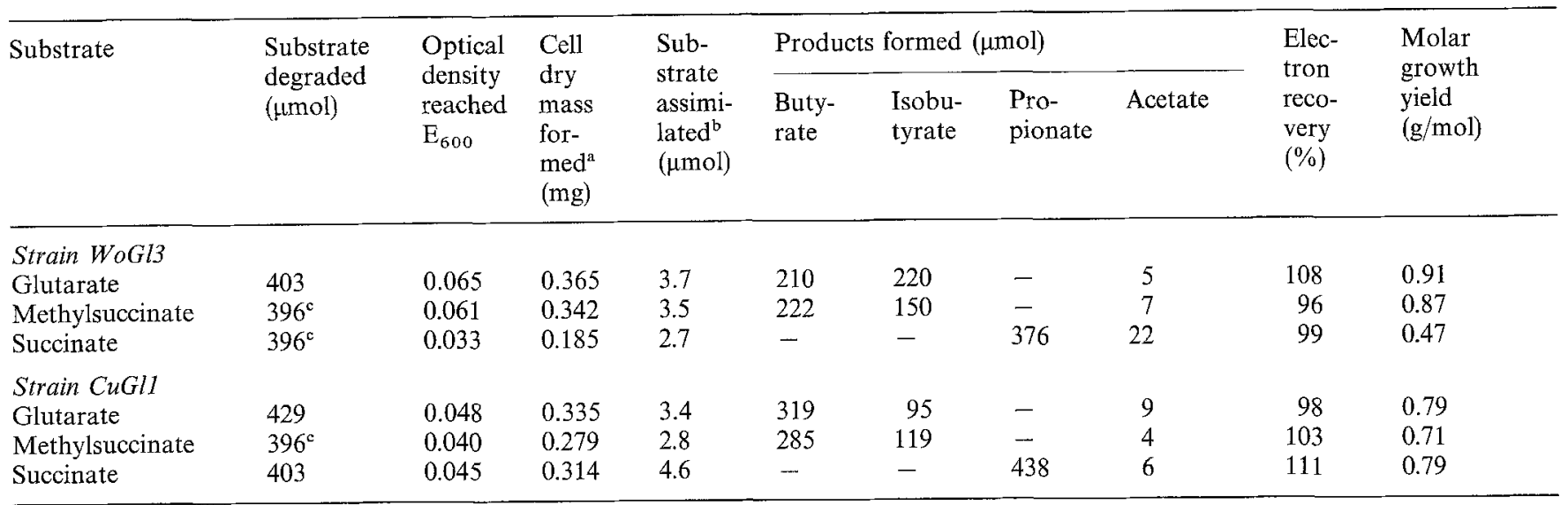

Growth experiments were carried out in duplicates in $22 \mathrm{ml}$ screw cap tubes

a Cell dry matter was calculated via cell turbidity using the conversion factors $0.1 \mathrm{OD}_{600} \cong 25.5 \mathrm{mg}$ cell dry matter per liter (WoGl3) and $0.1 \mathrm{OD}_{600} \cong 31.7 \mathrm{mg}$ cell dry matter per liter (CuGl1), which were obtained by direct gravimetric determinations in $500 \mathrm{ml}$ cultures grown with glutarate

b Substrate assimilated into cell material was calculated according to the following equations:

$21 \mathrm{C}_{5} \mathrm{H}_{8} \mathrm{O}_{4}+6 \mathrm{H}_{2} \mathrm{O} \rightarrow 20\left\langle\mathrm{C}_{4} \mathrm{H}_{7} \mathrm{O}_{3}\right\rangle+10 \mathrm{C}_{2} \mathrm{H}_{4} \mathrm{O}_{2}+5 \mathrm{CO}_{2}$

$3 \mathrm{C}_{4} \mathrm{H}_{6} \mathrm{O}_{4} \rightarrow 2\left\langle\mathrm{C}_{4} \mathrm{H}_{7} \mathrm{O}_{3}\right\rangle+1 \mathrm{C}_{2} \mathrm{H}_{4} \mathrm{O}_{2}+2 \mathrm{CO}_{2}$

c Substrate supplied

The following substrates were not degraded by strain WoGl3 in the presence of $2 \%$ rumen fluid (if not indicated otherwise, substrates were added $20 \mathrm{mM}$, sugars $5 \mathrm{mM}$ ): glutaconate, adipate, pimelate, suberate, malonate, oxalate, fumarate, methylglutarate, L- $\alpha$-hydroxyglutarate, mesaconate, itaconate, malate, lactate (10), citrate (10), pyruvate (10), glyoxylate, dipicolinate, formate, crotonate, butyrate (10), glucose, fructose, xylose, lactose, sucrose, arabinose, aspartate (10), glutamate (10), histidine, casamino acids $(0.1 \%)$, ethylene glycol (10), glycerol $(10)$, ethanol $(10)$, cadaverine (10). Degradation of fumarate, crotonate, mesaconate, maleinate, and itaconate was tested also in the presence of 5 or $20 \mathrm{mM}$ formate as external electron donor. No growth was observed with butyrate in a mixed culture experiment with Methanospirillum hungatei strain SK

CuG11. The results are presented in Table 1. The amounts of formed products agreed with complete substrate degradation. Small amounts of acetate $(<0.5 \mathrm{mM})$ were formed to balance the electron requirement of assimilative metabolism (Table 1). The molar growth yield of strain WoG13 with both glutarate and methylsuccinate was $0.9 \mathrm{~g}$ dry cell mass $\cdot \mathrm{mol}^{-1}$, and $0.5 \mathrm{~g}$ dry cell mass $\mathrm{mol}^{-1}$ with succinate. For strain CuGl1, growth yields were nearly the same with all 3 substrates tested $\left(0.7-0.8 \mathrm{~g} \cdot \mathrm{mol}^{-1}\right)$.

\section{Enzymes involved in energy metabolism of strain WoGl3}

Enzyme assays were carried out with cell-free extracts prepared from cells of strain WoGl3 grown with the respective substrate. Acyl-CoA : acetate CoA transferase, glutaryl-CoA dehydrogenase, glutaconyl-CoA decarboxylase, and butyryl-CoA dehydrogenase were detected at moderate activities, sometimes at less than $20 \%$ of in vivo activity (Table 2): during exponential growth at a growth rate of $0.033 \mathrm{~h}^{-1}$ at $30^{\circ} \mathrm{C}$ with a molar growth yield coefficient (Ys) of $0.9 \mathrm{~g} \cdot \mathrm{mol}^{-1}$, the rate of glutarate conversion was about $1200 \mathrm{nmol} / \mathrm{min} \cdot \mathrm{mg}$ protein.

The highest acyl-CoA : acetate $\mathrm{CoA}$ transferase activities were observed with butyryl-CoA and glutaryl-CoA as substrate, whereas activities with isobutyryl-CoA were considerably lower. Glutaryl-CoA synthetase could not be detected. Glutaryl-CoA dehydrogenase activity was found only with glutaryl-CoA; no dehydrogenase activity was detected with glutarate as substrate. Glutaryl-CoA dehydrogenase activity as well as butyryl-CoA dehydro-
Table 2. Enzymes involved in glutarate fermentation by strain WoGl3

\begin{tabular}{lc}
\hline Enzyme & $\begin{array}{l}\text { specific activity } \\
\text { (nmol/min } \cdot \text { mg protein) }\end{array}$ \\
\hline Glutaryl-CoA : acetate CoA transferase & 1300 \\
Butyryl-CoA : acetate CoA transferase & 1700 \\
Isobutyryl-CoA : acetate CoA transferase & 540 \\
Glutaryl-CoA dehydrogenase & $220^{\mathrm{a}}$ \\
Glutaconyl-CoA decarboxylase & 60 \\
Butyryl-CoA dehydrogenase & $300^{\mathrm{a}}$ \\
Methylmalonyl-CoA decarboxylase & 60
\end{tabular}

All enzyme activities were measured in cell-free extracts of glutarate-grown cells except for methylmalonyl-CoA decarboxylase which was determined with succinate-grown cells.

${ }^{a}$ measured with potassium hexacyanoferrate (III) as electron acceptor in the presence of PMS

genase activity measured with potassium hexacyanoferrate (III) and PMS (at catalytic concentrations) could not be enhanced by $0.01 \%(\mathrm{w} / \mathrm{v})$ Triton X-100.

The glutaconyl-CoA-decarboxylase activity was about $5 \%$ of the in vivo rate of glutarate conversion. Addition of Triton X-100 $(0.01 \%$ or $0.1 \%)$, ATP $(1 \mathrm{mM})$, thiamine pyrophosphate $(1 \mathrm{mM})$, biotin $(0.1 \mathrm{mM})$, coenzyme $\mathrm{B}_{12}(10-20 \mu \mathrm{M})$, FAD $(50 \mu \mathrm{M})$, $\mathrm{MgCl}_{2}(1-7.5 \mathrm{mM})$ or $\mathrm{CaCl}_{2}(1-2 \mathrm{mM})$ could not significantly enhance this activity. The decarboxylase activity was in the same range if the original aerobic assay of Buckel (1986) was used. With Acidaminococcus fermentans, activities of about $0.2 \mathrm{U} / \mathrm{mg}$ protein were 
observed with this assay. To ensure a sufficient activity of the auxiliary enzyme mixture in the glutaconyl-CoA decarboxylase assay the activity of glutaconate CoAtransferase was measured as a representative.

In cell-free extracts prepared from methylsuccinategrown cells, glutaryl-CoA dehydrogenase activity was considerably lower $(78 \mathrm{nmol} / \mathrm{min} \cdot \mathrm{mg}$ protein) than in glutarate-grown cells. Neither isomerization of glutarylCoA to methylsuccinyl-CoA nor rearrangement of methylsuccinate to glutarate could be detected in the presence of coenzyme $B_{12}$ in cell-free extracts of these cells.

The key enzyme of succinate fermentation, methylmalonyl-CoA decarboxylase, was detected in succinategrown cells $(60 \mathrm{nmol} / \mathrm{min} \cdot \mathrm{mg}$ protein) but not in glutarate-grown cells.

\section{Enzymes involved in assimilatory metabolism of strain WoGl3}

Enzyme activities of $\beta$-oxidation, thiolytic fatty acid cleavage, and of phosphate acetyl transferase and acetate kinease were detected in cell-free extracts (Table 3 ). The activities were sufficient to provide the redox equivalents for synthesis of cell matter from glutarate (calculated minimum activity: $9.2 \mathrm{nmol} / \mathrm{min} \cdot \mathrm{mg}$ protein).

\section{Discussion}

\section{Physiology}

In the present study, we describe two strains of glutaratefermenting bacteria enriched and isolated from anoxic freshwater and saltwater sediment samples. Strain WoG13 appeared to be adapted to low salt concentrations as typical of a freshwater sediment. Its high growth

Table 3. Enzymes involved in assimilatory metabolism of strain WoGl3

\begin{tabular}{lc}
\hline Enzyme & $\begin{array}{l}\text { Specific activity } \\
\text { (nmol/min ' mg protein) }\end{array}$ \\
\hline Crotonase & 84 \\
3-Hydroxybutyryl-CoA dehydrogenase & 490 \\
$\beta$-Ketothiolase & 280 \\
Phosphate acetyl transferase & 46 \\
Acetate kinase & 170 \\
\hline
\end{tabular}

temperature optimum $\left(37^{\circ} \mathrm{C}\right)$ indicates that this bacterium is also adapted to the intestinal tract of warmblooded animals. The isolate from marine sediment behaved more like an estuary organism tolerating salt concentrations up to $2 \% \mathrm{NaCl}$ and $0,3 \% \mathrm{MgCl}_{2}(\mathrm{w} / \mathrm{v})$.

Strain WoGl3 was described here in more detail and is the first strictly anaerobic bacterium fermenting glutarate in pure culture. This strain is very specialized and grows only with dicarboxylic acids, decarboxylating them to the respective fatty acids. Glutarate and methylsuccinate fermentation formed butyrate and isobutyrate whereas succinate was fermented to propionate. Thus, besides oxalate, malonate, and succinate, also the dicarboxylic acid glutarate can be fermented via decarboxylation. This is possible although three methylene groups separate the two carboxylic groups of glutarate and decrease the inductive effect onto each other. Thus, decarboxylation of glutarate has to be prepared through activation and by increasing the electron-attracting effect at the $\beta$-carbon atom. Measurements of enzyme activities in cell-free extracts of strain WoGl3 led to the pathway of glutarate degradation shown in Fig. 3.

Activation of glutarate to glutaryl-CoA is carried out by a $\mathrm{CoA}$ transferase rather than by a glutaryl-CoA synthetase enzyme. The enzyme catalyzing the CoA transfer reaction probably uses acetyl-CoA as CoA source. The pool of acetyl-CoA is replenished by CoA transfers from butyryl-CoA and isobutyryl-CoA to acetate releasing the fermentation products butyrate and isobutyrate. It is not clear yet whether one single acylCoA : acetate CoA transferase catalyzes three reactions with different acyl residues, or whether two or three different enzymes are involved. Oxidation of glutarylCoA to glutaconyl-CoA polarizes the linkage between the carbon atoms 4 and 5 and allows subsequent decarboxylation to crotonyl-CoA. The same reaction steps are active also in aerobic glutarate degradation (Numa et al. 1964). Crotonyl-CoA is reduced to butyryl-CoA with the reducing equivalents released by glutaryl-CoA dehydrogenase. The electron transfer might be mediated by an electron carrier of a redox potential in the range of that of the crotonyl-CoA/butyryl-CoA couple $\left(\mathrm{E}^{\circ r}=-126 \mathrm{mV}\right.$, Gustafson et al. 1986) and of the glutaconyl-CoA/glutaryl-CoA couple which is assumed to be in the same range. The physiological electron carrier

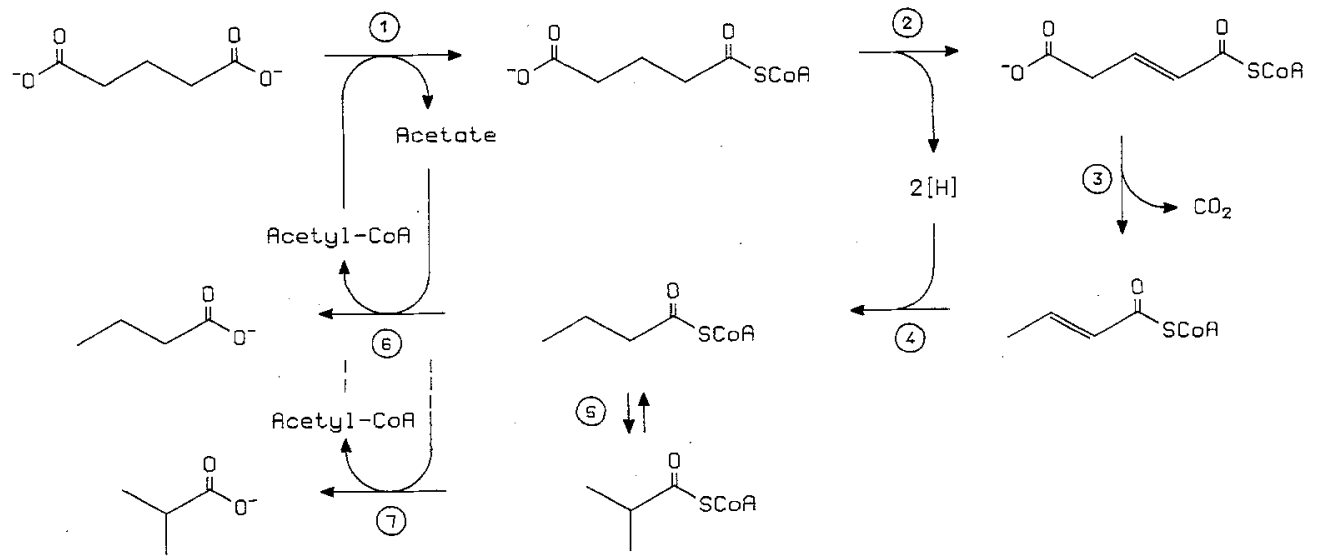

Fig. 3. Pathway of fermentative glutarate degradation by strain WoG13. Numbers in circles refer to the following enzymes: (1) glutaryl-CoA: acetate $\mathrm{CoA}$ transferase, (2) glutaryl-CoA dehydrogenase, (3) glutaconyl-CoA decarboxylase, (4) butyryl-CoA dehydrogenase, (5) butyryl-CoA: isobutyryl-CoA mutase, (6) butyryl-CoA:acetate $\mathrm{CoA}$ transferase, (7) isobutyryl-CoA : acetate CoA transferase 
is not known yet. Formation of isobutyrate as fermentation side product proceeds via isomerization of butyrylCoA to isobutyryl-CoA through butyryl-CoA : isobutyryl-CoA mutase and $\mathrm{CoA}$ transfer to acetate as mentioned above. This rearrangement is characterized in more detail in a separate paper (Matthies and Schink 1992); the slight increase in entropy of the total reaction through this isomerization may be the only advantage for the bacterium.

Decarboxylation of glutarate to butyrate and isobutyrate can obviously support the whole energy metabolism of strain WoGl3:

$$
\begin{gathered}
{\text { 1 } \text { Glutarate }^{2-}+\mathrm{H}^{+} \rightarrow}_{0.5 \text { Butyrate }^{-}+0.5 \text { Isobutyrate }^{-}+\mathrm{CO}_{2}} \\
\Delta \mathrm{G}^{\circ \prime}=-25.4 \mathrm{~kJ} \cdot \mathrm{mol}^{-1}
\end{gathered}
$$

(calculated after Thauer et al. 1977)

The small free energy change of this reaction would allow synthesis of only one third of an ATP, taking into account that irreversible ATP synthesis in the living cell requires $60-80 \mathrm{~kJ} \cdot \mathrm{mol}^{-1}$ (Thauer et al. 1977). With this assumption, one can calculate from the measured growth yield (Table 1) $\mathrm{Y}_{\text {ATP }}$ to $2.7 \mathrm{~g}$ dry cell mass/mol ATP which is rather low compared to that of other anaerobic bacteria (5-15 g dry cell mass/mol ATP; Stouthamer 1979). The low growth rate of $0.033 \mathrm{~h}^{-1}\left(\mathrm{t}_{\mathrm{d}}=21 \mathrm{~h}\right)$ at $30^{\circ} \mathrm{C}$ may be the main reason for this low $Y_{A T P}$ value: The part of the total energy budget that has to be spent in maintenance metabolism is comparably high at low growth rates (Pirt 1965).

The free energy change of fermentative glutarate degradation $\left(\Delta \mathrm{G}^{\circ \prime}=-25.4 \mathrm{~kJ} \cdot \mathrm{mol}^{-1}\right)$ does not allow ATP synthesis by substrate-linked phosphorylation. There is also no indication of an electron transport chain involved in energy metabolism of this bacterium. In the last few years, two different mechanisms of energy conservation were described for bacteria growing by decarboxylation of dicarboxylic acids to the respective fatty acids. The succinate-fermenting bacterium Propionigenium modestum couples the membrane-associated methylmalonyl-CoA decarboxylase reaction with sodium ion transport across the cytoplasmic membrane (Hilpert et al. 1984). The $\mathrm{Na}^{+}$gradient is used directly for ATP synthesis by a $\mathrm{Na}^{+}$-dependent ATPase (Laubinger and Dimroth 1988). In Oxalobacter formigenes, the exergonic decarboxylation of oxalate to formate drives an electrogenic antiporter system which exchanges oxalate for formate. The decarboxylating enzyme localized in the cytoplasm consumes one mol of protons per mol oxalate thus building up a transmembrane proton gradient which drives ATP synthesis (Anantharam et al. 1989). In strain WoGl3, glutaconyl-CoA decarboxylase appears to be the key enzyme in glutarate catabolism and is probably directly involved in energy conservation. Unfortunately, the activity of this enzyme in cell-free extracts was very low and could not be enhanced by various additions to the assay mixture. Obviously, the decarboxylase is very unstable in crude cell-free extracts and nearly $95 \%$ of the present decarboxylase became inactive during the preparation of the cell-free extracts. The biochemistry of this decarboxylation as well as the mechanism of energy conservation will be subject of further studies in our laboratory.

\section{Taxonomy}

The new glutarate-fermenting isolate strain WoGl3 is a strictly anaerobic, gram-negative, sporeforming bacterium. With respect to gram reaction, DNA guanine-pluscytosine content and the small range of substrates used, our isolate resembles the species Oxalobacter formigenes (Allison et al. 1985), Oxalobacter vibrioformis (Dehning and Schink 1989a) and Malonomonas rubra (Dehning and Schink 1989b) which all ferment exclusively dicarboxylic acids. However, strain WoG13 differs from these species by their inability to form spores, and to use glutarate, methylsuccinate or succinate as energy and carbon source. In addition, the Oxalobacter species are in most cases short rods or vibroid cells, and $\mathrm{Ma}$ lonomonas rubra differs by its very high cytochrome content.

At present, the genus Sporomusa is the only genus which includes Gram-negative, sporeforming bacteria. Within this genus, six species habe been described which have guanine-plus-cytosine values in the range of $42-48 \mathrm{~mol}^{\%}$. Two species, S. termitida and S. malonica, can use dicarboxylic acids as substrates: they decarboxylate succinate and malonate (Breznak et al. 1988; Dehning et al. 1989). However, our isolate differs from these and the four other species (Möller et al. 1984; Ollivier et al. 1985; Hermann et al. 1987) by its non-acetogenic metabolism and the small range of substrates used.

Thus, with its physiological properties strain WoGl3 does not fit with any of the genera mentioned. For correct assignment of this new isolate to a taxonomic entity, $16 \mathrm{~S}$ rRNA analysis has to be carried out.

Strain WoGl3 was deposited with the Deutsche Sammlung von Mikroorganismen GmbH, Braunschweig, under the number DSM 6652.

Acknowledgements. We thank Dr. M. Stieb for kindly providing the glutarate-degrading enrichment cultures. We are indebted to Prof. Dr. W. Buckel, Marburg, for helpful discussions and for providing auxiliary enzymes for the glutaconyl-CoA decarboxylase assay. Financial support by the DFG is gratefully acknowledged.

\section{References}

Alison MS, Dawson KA, Mayberry WR, Foss JG (1985) Oxalobacter formigenes gen. nov., sp. nov.: oxalate-degrading anaerobes that inhabit the gastrointestinal tract. Arch Microbiol 141: $1-7$

Anantharam V, Allison MJ, Maloney PC (1989) Oxalate: formate exhange: the basis for energy coupling in Oxalobacter. $\mathrm{J}$ Biol Chem 264: 7244-7250

Bak F, Widdel F (1986) Anaerobic degradation of phenol and phenol derivatives by Desulfobacterium phenolicum sp. nov.. Arch Microbiol 146: 177-180

Bartholomew JW (1962) Variables influencing results, and precise definition of steps in gram staining as a means of standardizing the results obtained. Stain Technol 37: 139-155 
Bergmeyer HU (1974) Methoden der enzymatischen Analyse, 3rd edn. Verlag Chemie, Weinheim, FRG

Blenden DC, Goldberg HS (1965) Silver impregnation stain for Leptospira and flagella. J. Bacteriol 89:899-900

Brandis-Heep A, Gebhardt NA, Thauer RK, Widdel F, Pfennig N (1983) Anaerobic acetate oxidation to $\mathrm{CO}_{2}$ by Desulfobacter postgatei. 1. Demonstration of all enzymes required for the operation of the citric acid cycle. Arch Microbiol 136:222-229

Breznak JA, Switzer JM, Seitz H-J (1988) Sporomusa termitida sp. nov., an $\mathrm{H}_{2} / \mathrm{CO}_{2}$-utilizing acetogen isolated from termites. Arch Microbiol 150: 282-288

Buckel W (1986) Biotin-dependent decarboxylases as bacterial sodium pumps: purification and reconstitution of glutaconylCoA decarboxylase from Acidaminococcus fermentans. In: Fleischer S, Fleischer B (eds) Methods in enzymology, vol 125. Academic Press, New York London, pp 547-558

De Ley J, Cattoir H, Reynaerts A (1970) The quantitative measurement of DNA hybridization from renaturation rates. Eur $\mathrm{J}$ Biochem 12: 133-143

Dehning I, Schink B (1989a) Two species of anaerobic oxalatefermenting bacteria, Oxalobacter vibrioformis sp. nov. and Clostridium oxalicum sp. nov., from sediment samples. Arch Microbiol 153: 79-84

Dehning I, Schink B (1989b) Malonomonas rubra gen. nov., sp. nov., a microaerotolerant anaerobic bacterium growing by decarboxylation of malonate. Arch Microbiol 151: 427-433

Dehning I, Stieb M, Schink B (1989) Sporomusa malonica sp. nov., a homoacetogenic bacterium growing by decarboxylation of malonate or succinate. Arch Microbiol 151: 421-426

Denger K, Schink B (1990) New motile anaerobic bacteria growing by succinate decarboxylation to propionate. Arch Microbiol 154: $550-555$

Gregersen T (1978) Rapid method for distinction of Gram-negative from Gram-positive bacteria. Eur J Appl Microbiol Biotechnol 5: $123-127$

Gustafson WG, Feinberg Ba, McFarland JT (1986) Energetics of $\beta$-oxidation. Reduction potentials of general fatty acyl-CoA dehydrogenase, electron transfer flavo protein, and fatty acylCoA substrates. J Biol Chem 261: 7733-7741

Hermann M, Popoff M-R, Sebald M (1987) Sporomusa paucivorans sp. nov., a methylotrophic bacterium that forms acetic acid from hydrogen and carbon dioxide. Int Syst Bacteriol 37: 93-101

Hilpert W, Dimroth P (1983) Purification and characterization of a new sodium-transport decarboxylase. Methylmalonyl-CoA decarboxylase from Veillonella alcalescens. Eur J Biochem 132: $579-587$

Hilpert W, Schink B, Dimroth P (1984) Life by a new decarboxylation dependent energy conservation mechanism with $\mathrm{Na}^{+}$as coupling ion. EMBO J 3: 1665-1670

Hollaus F, Sleytr U (1972) On the taxonomy and fine structure of some hyperthermophilic saccharolytic clostridia. Arch Mikrobiol 86: $129-146$

Imhoff-Stuckle D, Pfennig N (1983) Isolation and characterization of a nicotinic acid degrading sulfate-reducing bacterium, Desulfococcus niacini sp. nov. Arch Microbiol 136: 194-198

Laubinger W, Dimroth P (1988) Characterization of the ATP synthase of Propionigenium modestum as a primary sodium pump. Biochem 27: 7531-7537

Lynen F, Ochoa S (1953) Enzymes of fatty acid metabolism. Biochim Biophys Acta 12: 299-314

Marmur J (1961) A procedure for the isolation of deoxyribonucleic acid from micro-organisms. J Mol Biol 3: 208-218

Matthies C, Schink B (1992) Reciprocal isomerization of butyrate and isobutyrate by strain WoGl3 and methanogenic isobutyrate degradation by a defined triculture. Appl Environ Microbiol (in press)

Metcalfe LD, Schmitz AA, Pelka JR (1966) Rapid preparations of fatty acids esters from lipids for gaschromatographic analysis. Anal Chem 38: 514-515
Möller B, Oßmer R, Howard BH, Gottschalk G, Hippe H (1984) Spromusa, a new genus of Gram-negative anaerobic bacteria including Sporomusa sphaeroides spec nov. and Sporomusa ovata spec. nov. Arch Microbiol 139: 388-396

Moskowitz GJ, Merrick JM (1969) Metabolism of poly- $\beta$-hydroxybutyrate. II. Enzymatic synthesis of $D$-(-) $\beta$-hydroxybutyryl coenzyme A by an enoyl hydrase from Rhodospirillum rubrum. Biochem 8: 2748-2755

Numa S, Ishimura Y, Nakazawa T, Okazaki T, Hayaishi O (1964) Enzymic studies on the metabolism of glutarate in Pseudomonas. J Biol Chem 239: 3915-3926

Ollivier B, Cord-Ruwisch R, Lombardo A. Garcia JL (1985) Isolation and characterization of Sporomusa acidovorans sp. nov., a methylotrophic homoacetogenic bacterium. Arch Microbiol 142: $307-310$

Pfennig N, Trüper HG (1981) Isolation of members of the families Chromatiaceae and Chlorobiaceae In: Starr, MP, Stolp H, Trüper HG, Balows A, Schlegel HG (eds) The prokaryotes, vol I, Springer, Berlin Heidelberg New York, pp 279-289

Pirt SJ (1965) The maintenance energy of bacteria in growing cultures. Proc R Soc Lond [Biol] 163B: 224-231

Platen H, Schink B (1989) Anaerobic degradation of acetone and higher ketones via carboxylation by newly isolated denitrifying bacteria. J Gen Microbiol 135: 883-891

Schink B, Pfennig N (1982) Propionigenium modestum gen. nov. sp. nov., a new strictly anaerobic, nonsporing bacterium growing on succinate. Arch Microbiol 133: 209-216

Schnell S, Bak F, Pfennig N (1989) Anaerobic degradation of aniline and dihydroxybenzenes by newly isolated sulfate-reducing bacteria and description of Desulfobacterium anilini. Arch Microbiol 152: 556-563

Smith RL, Strohmaier FE, Oremland RS (1985) Isolation of anacrobic oxalate-degrading bacteria from freshwater lake sediments. Arch Microbiol 141: 8-13

Sparling R, Daniels L (1987) The specifity of growth inhibition of methanogenic bacteria by bromethanesulfonate. Can J Microbiol 33: 1132-1136

Stams AJM, Kremer DR, Nicolay K, Hansen TA (1984) Pathway of propionate formation in Desulfobulbus propionicus. Arch Microbiol 139: 167"-173

Stieb M (1985) Anaerober bakterieller Abbau von Mono- und Dicarbonsäuren durch Reinkulturen und methanogene Mischkulturen. Thesis, University of Konstanz, Faculty of Biology

Stjernholm R, Wood HG (1961) Methylmalonyl isomerase, II. Purification and properties of the enzyme from propionibacteria. Proc Natl Acad Sci USA 47: 303-312

Stouthamer AG (1979) The search for correlation between theoretical and experimental growth yields. In: Quayle JR (ed) International review of biochemistry, microbial biochemistry, vol 21. University Park Press, Baltimore, pp 1-47

Szewzyk R, Pfennig N (1987) Complete oxidation of catechol by the strictly anaerobic sulfate-reducing Desulfobacterium catecholicum sp, nov.. Arch Microbiol 147: 163-168

Thauer RK, Jungermann K, Decker K (1977) Energy conservation of chemotrophic anaerobic bacteria. Bacteriol Rev 4.1:100-180

Widdel F, Pfennig N (1981) Studies on dissimilatory sulfate-reducing bacteria that decompose fatty acids. I. Isolation of new sulfate reducing bacteria enriched with acetate from saline environments. Description of Desulfobacter postgatei gen. nov., sp. nov.. Arch Microbiol 129: 395-400

Widdel F, Kohring GW, Mayer F (1983) Studies on dissimilatory sulfate-reducing bacteria that decompose fatty acids. III. Characterization of the filamentous gliding Desulfonema limicola gen. nov., sp. nov., and Desulfonema magnum sp. nov.. Arch Microbiol 134: 286-294

Zamenhoff S (1957) Preparation and assay of desoxyribonucleic acid from animals tissue. In: Colowick SP, Kaplan NO (eds) Methods in enzymology, vol 3. Academic Press, New York London pp 696-704 